\title{
Paclobutrazol and branch tip pruning on the flowering induction and quality of mango tree fruits ${ }^{1}$
}

\author{
Girlaine Pereira Oliveira ${ }^{2}$, Dalmo Lopes de Siqueira ${ }^{3}$, \\ Luiz Carlos Chamhum Salomão ${ }^{3}$, Paulo Roberto Cecon ${ }^{4}$, Daniel Lucas Magalhães Machado 5
}

\begin{abstract}
The 'Ubá' mango tree cultivar is very important for the juice industry in the "Zona da Mata" region of the Minas Gerais State, in Brazil, but problems such as uneven flowering and low yield have discouraged producers. This study aimed at evaluating the effect of paclobutrazol, combined with branch tip pruning, on the flowering induction and quality of 'Ubá' mango tree fruits. Treatments were distributed in a $5 \times 2+1$ factorial arrangement, consisting of five paclobutrazol doses $(0 \mathrm{~g}, 0.50 \mathrm{~g}, 1.00 \mathrm{~g}, 1.50 \mathrm{~g}$ and $2.0 \mathrm{~g}$ per linear meter of canopy), with and without branch tip pruning, in a randomized blocks design, with four replicates. The flowering percentage, number of panicles per branch, total flowers per panicle, male/ hermaphrodite flowers ratio, number of fruits per branch and fruit quality were evaluated. Plants treated with tip pruning showed a higher flowering percentage. There was an increase in the flowering percentage in response to the paclobutrazol dose, reaching a maximum level at the dose of $1.62 \mathrm{~g}$ per linear meter of canopy. Plants submitted to branch tip pruning had a higher number of panicles per branch. There was an increase in the male/hermaphrodite flowers ratio with increasing paclobutrazol doses. Branch tip pruning increased the number of fruits per branch. There were no differences in fruit quality in response to the paclobutrazol application. It was concluded that the paclobutrazol application at the dose of $1.62 \mathrm{~g}$ per linear meter of canopy, combined with branch tip pruning, increases the flowering of the 'Ubá' mango tree and does not change the fruit quality.
\end{abstract}

KEYWORDS: Mangifera indica L.; flowering induction; growth regulator.

\section{INTRODUCTION}

The 'Ubá' mango cultivar shows characteristics desirable to industrial processing in the "Zona da Mata" region of the Minas Gerais State, in Brazil,

\section{RESUMO}

Paclobutrazol e desponte de ramos no florescimento e qualidade de frutos de mangueira

A mangueira 'Ubá' é muito importante para as indústrias produtoras de suco na região da Zona da Mata Mineira, mas problemas como florescimento desuniforme e baixa produtividade têm desestimulado os produtores. Objetivou-se avaliar a eficiência do paclobutrazol, aliado ao desponte de ramos, na indução do florescimento e na qualidade dos frutos da mangueira 'Ubá'. Os tratamentos foram distribuídos em esquema fatorial $5 \times 2+1$, sendo compostos por cinco doses de paclobutrazol ( $0 \mathrm{~g} ; 0,50 \mathrm{~g} ; 1,00 \mathrm{~g}$; 1,50 g; e 2,0 g por metro linear de copa), com e sem desponte dos ramos, em delineamento de blocos casualizados, com quatro repetições. Foram avaliados a porcentagem de florescimento, número de panículas por ramo, total de flores por panícula, razão entre flores masculinas e hermafroditas, número de frutos por ramo e qualidade dos frutos. Plantas tratadas com desponte apresentaram maior porcentagem de florescimento. Houve acréscimo na porcentagem de florescimento em resposta à dose de paclobutrazol, atingindo nível máximo na dosagem de 1,62 g por metro linear da copa. Plantas com desponte dos ramos apresentaram maior número de panículas por ramo. O incremento na dose de paclobutrazol aumentou a razão entre flores masculinas e hermafroditas. $\mathrm{O}$ desponte dos ramos aumentou o número de frutos por ramo. Não houve diferenças na qualidade dos frutos em resposta à aplicação do paclobutrazol. Conclui-se que a aplicação de paclobutrazol até a dose de 1,62 g por metro linear da copa, aliada ao desponte, aumenta o florescimento da mangueira 'Ubá' e não altera a qualidade dos frutos.

PALAVRAS-CHAVE: Mangifera indica L.; indução de florescimento; regulador de crescimento.

due to its attractive pulp color, high soluble solids contents and excellent flavor, which make its juice appreciated by consumers (Silva et al. 2012, Oliveira et al. 2013). However, its flowering occurs unevenly, what may take place only in one part of the canopy

1. Manuscript received in Oct./2016 and accepted for publication in Feb./2017 (http://dx.doi.org/10.1590/1983-40632016v4743861).

2. Universidade de São Paulo, Escola Superior de Agricultura "Luiz de Queiroz”, Departamento de Fitotecnia, Piracicaba, SP,

Brazil.E-mail: girlaine.pereira@usp.br.

3. Universidade Federal de Viçosa, Departamento de Fitotecnia, Viçosa, MG, Brazil.E-mails: siqueira@ufv.br, 1salomao@ufv.br. 4. Universidade Federal de Uberlândia, Departamento de Fitotecnia, Uberlândia, MG, Brazil.

E-mail: danielmagalhaes_agro@yahoo.com.br.

5. Universidade Federal de Viçosa, Departamento de Estatística, Viçosa, MG, Brazil. E-mail: cecon@ufv.br 
at a time, leading to an uneven fruit maturation and resulting in a sequential harvest (Silva et al. 2012), increasing production costs.

The use of growth regulators is a common practice in mango cultivation under semi-arid conditions, mainly with 'Tommy Atkins' and 'Palmer' cultivars, for which doses, times and forms of application have been defined as part of technologies to increase flowering and production (Mouco \& Albuquerque 2005, Mouco et al. 2010, Coelho et al. 2014, Oliveira et al. 2015). In addition, paclobutrazol acts by reducing the gibberellins biosynthesis (Taiz \& Zeiger 2012), thus contributing to inhibit branch growth (Mouco et al. 2011), promoting bud maturation and consequently favoring flowering (Davenport 2007).

The floral induction management may be associated with the removal of the tip of productive branches (branch tip pruning). This practice results in flowering uniformity and production of more panicles per branch of the 'Palmer' mango, in northern Minas Gerais State (Oliveira et al. 2015). According to Davenport (2006), the removal of the apex of branches stimulates the budding of axillary buds and removes structures that inhibit reproductive buds.

This study aimed at evaluating the effect of paclobutrazol doses combined with branch tip pruning on the flowering induction and quality of 'Ubá' mango tree fruits.

\section{MATERIAL AND METHODS}

The experiment was conducted with the 'Ubá' mango cultivar, at the Universidade Federal de Viçosa (42 $52^{\circ} 40^{\prime \prime} \mathrm{W}, 20^{\circ} 45^{\prime} 20^{\prime}$ 'S and altitude of $651 \mathrm{~m}$ ), Minas Gerais State, Brazil. According to the Köppen classification, the climate of the region is Cwa, mesothermic, with hot and rainy summers and cold and dry winters. Rainfall levels and average temperatures during the experimental period are shown in Figure 1.

The 'Ubá' mango orchard was implanted in March 2010, with spacing of $7 \mathrm{~m}$ x $6 \mathrm{~m}$. On December 13 (2013), branch tip pruning was carried out to standardize sprouting, regarding branch vigor and age, and to eliminate diseased, poorly located and weak branches. Central opening and lifting of canopy were also performed. The orchard did not receive irrigation throughout the experimental period because the aim was to keep the same cultivation conditions of the 'Ubá' mangoes grown in the "Zona da Mata" region of the Minas Gerais State. Liming was carried out in October 2013 ( 3 ton ha-1) to supply the need for calcium and magnesium. Fertilization was carried out according to the soil and foliar analysis (Pinto et al. 2009), taking place in November, December and January of 2013 and 2014. For each month, $150 \mathrm{~g}$ of urea, $150 \mathrm{~g}$ of potassium chloride and $15 \mathrm{~g}$ of borax were added. In November, $800 \mathrm{~g}$ of simple superphosphate were also applied.

The experiment was set up in a $5 \times 2+1$ factorial scheme, being the first factor five paclobutrazol doses $(0 \mathrm{~g}, 0.50 \mathrm{~g}, 1.00 \mathrm{~g}, 1.50 \mathrm{~g}$ and $2.0 \mathrm{~g}$ per linear meter of canopy) and the second one the branch tip pruning (with and without). The experimental design was randomized blocks, with four replicates and one plant per plot. In each block, one additional treatment was added, in which plants did not receive any of the treatments used in the experiment nor branch tip pruning.

Paclobutrazol was applied to avoid the emission of the third vegetative growth flow and promote flowering. For the paclobutrazol application in the soil, a moderate rainfall rate of approximately $10 \mathrm{~mm}$ was expected on April 11 (2014), when plants presented two flowering fluxes. The paclobutrazol source was Cultar 250 SC (Syngenta), with $25 \%$ of active ingredient. The commercial product containing paclobutrazol was diluted in $2 \mathrm{~L}$ of water, according to the doses calculated, and applied to the canopy projection, where the highest number of absorbent roots is found.

Three applications of $3 \%$ potassium sulphate $\left(\mathrm{K}_{2} \mathrm{SO}_{4}\right)$ by volume of $4 \mathrm{~L}$ of syrup per plant were

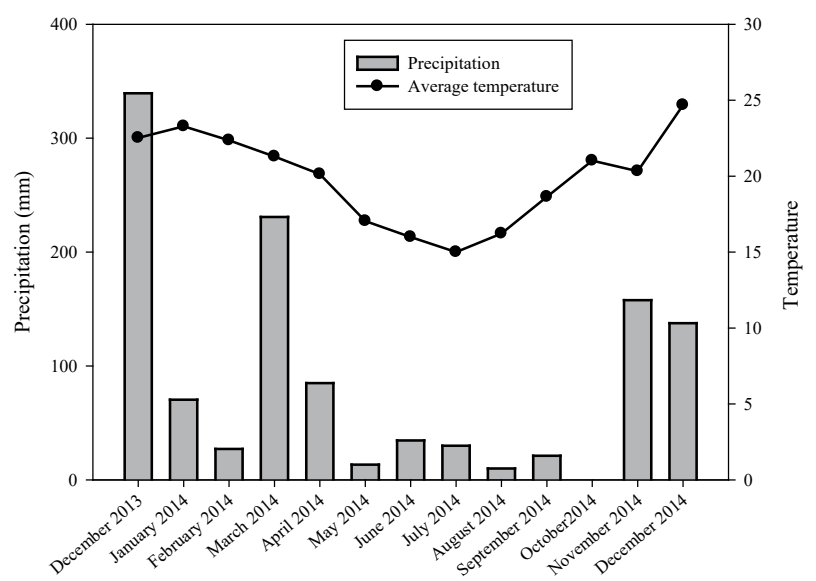

Figure 1. Rainfall and monthly average temperature $\left({ }^{\circ} \mathrm{C}\right)$ in Viçosa, Minas Gerais State, Brazil, in 2013/2014. 
carried out to aid branch maturation. The first $\mathrm{K}_{2} \mathrm{SO}_{4}$ application was performed at 50 days after the paclobutrazol application (May 30, 2014) and the second one on June 06, 2014. Ethephon (Ethrel 720), at a dose of $50 \mathrm{~mL}$ for every $100 \mathrm{~L}$ of water, was added at the last application, performed on June 18, 2014. After 75 days of the paclobutrazol application, branches were pruned according to treatments (June $26,2014)$, cutting the branch tip with a pruning shear, approximately $5 \mathrm{~cm}$ below its apex.

From the pruning of plants, calcium nitrate was applied at 90 days after the paclobutrazol application, at the concentration of $2 \%$ in the volume of $4 \mathrm{~L}$ of syrup per plant, in order to induce sprouting. Four applications were made on July 3, 10, 17 and 24 (2014).

After full blooming, the following evaluations were performed: flowering percentage, number of panicles per branch, total number of flowers per panicle and number of hermaphrodite and male flowers per panicle. In each plant quadrant, the number of branches of the second flowering stage was measured, and then the number of branches with panicles in each quadrant was counted to calculate the flowering percentage in the plant, using the following formula: Flowering percentage $=[$ number of branches with panicle/total number of branches x 100]. The number of panicles per branch was evaluated in three randomly chosen branches per quadrant, totaling 12 branches per plant.

Flowering uniformity was evaluated through field observations and plants photos. One panicle was collected from each plant and, from this panicle, with the aid of a magnifying glass, the number of male and hermaphrodite flowers, as well as total flowers, were counted.

After the physiological fall of fruits, at 60 days before harvest, with the fruits in full development, the number of fruits per branch was counted.

At harvest time, 10 physiologically mature fruits were selected from each experimental plot. Fruits were washed and treated with the Prochloraz fungicide (Sportak $450 \mathrm{CE}, 45 \%$ of active ingredient),

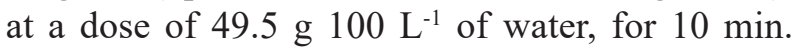
After drying, fruits were immersed in an ethephon solution (Ethrel 240, $24 \%$ of active ingredient), at a concentration of $1 \mathrm{~g}$ (a.i.) $\mathrm{L}^{-1}$ and stored at room temperature. Three days after the treatment with ethephon, the following evaluations were performed: length, ventral (smaller) and transverse (larger) fruit diameter (using a caliper), pulp yield, soluble solids content and titratable acidity.

To determine pulp yield, fruits were weighed in an precision electronic balance of $0.1 \mathrm{~g}$ (Diamond A04), then peeled and pulped. Peels and seeds were weighed. Pulp mass was determined by subtraction (fruit mass - peel mass - seed mass). Pulp yield was calculated using the following formula: (pulp mass/ fruit mass) x 100 .

Fruit pulp was ground and homogenized in a blender to determine soluble solids (SS) and titratable acidity (TA). Soluble solids were determined by making three readings with a portable refractometer (Atago model N1), in the range of 0-32 ${ }^{\circ}$ Brix. Data were expressed as ${ }^{\circ}$ Brix. Pulp titratable acidity was determined using composite samples with mass of approximately $5.0 \mathrm{~g}$. Samples were diluted in $100 \mathrm{~mL}$ of distilled water in Erlenmeyer flasks. Three drops of $1 \%$ phenolphthalein indicator were added to this solution and titrations were carried out under stirring with a $0.1 \mathrm{~N} \mathrm{Na}(\mathrm{OH})$ solution, previously standardized with potassium biftalate. The results were expressed as $\mathrm{g}$ of citric acid per $100 \mathrm{~g}$ of pulp. The total soluble solids/titratable acidity ratio was obtained using the following the formula: TSS/TA (AOAC 1997).

Data were submitted to analysis of variance. For characteristics with significant differences, the Dunnett test was performed to compare with the control, as well as the Tukey test was applied to compare means with significant interaction. The growth regulator doses effects were tested and adjusted to a regression equation. Saeg was the statistical software used (Saeg 2007).

\section{RESULTS AND DISCUSSION}

The flowering of control plants occurred on July 03 (2014). In plants not submitted to tip pruning, it occurred on August 10 (2014), while in plants submitted to tip pruning it occurred on September 02 (2014). An uneven flowering was observed on the canopy of control plants, with the presence of floral buds, developing panicles and panicles with floral opening in the same plant (Figures 2A and $2 \mathrm{~B})$. On the other hand, in plants with tip pruning, the development of floral buds and panicles occurred uniformly in the entire canopy, i.e., they all began the emission of floral buds at the same moment (Figures 2C and 2D). 
The uniform emergence of floral buds in pruned plants occurred because the post-harvest pruning allowed the renewal of shoots, resulting in the formation of more homogenous and more vigorous buds for the next harvest. After pruning, branches with the same age and physiological stage emerge (Davenport 2006).

Branch tip pruning provided a higher percentage of flowering and a higher number of fruits per branch of 'Ubá' mango trees. Plants submitted to branch tip pruning and paclobutrazol application had a higher number of panicles per branch. Control plants presented a higher number of hermaphrodite flowers in the panicle (Table 1).

The increase in the paclobutrazol dose provided a higher flowering percentage, whose values were higher in the presence of $1.62 \mathrm{~g}$ of paclobutrazol per linear meter of canopy (Figure 3A).
Branch tip pruning also increased the flowering percentage of 'Ubá' mango by more than $30 \%$ (Figure 3B). Paclobutrazol is one of the inhibitors of gibberellin synthesis, promoting floral induction (Davenport 2007), since gibberellins are flowering inhibitors of mango and other fruits (Taiz \& Zeiger 2012, Davenport \& Núñes-Eliséa 1997). Paclobutrazol, associated with climatic conditions and branch maturation, induces conditions favorable to flowering, and the combined application of this product with nitrate sprays stimulates floral initiation (Davenport 2007), what justifies the higher flowering percentage observed from the dose of $1.62 \mathrm{~g} \mathrm{~m}^{-1}$ (Figure 3A).

The high flowering percentage observed in plants submitted to paclobutrazol application was also observed by Cardoso et al. (2007), Chatzivagiannis et al. (2014) and Coelho et al. (2014), respectively
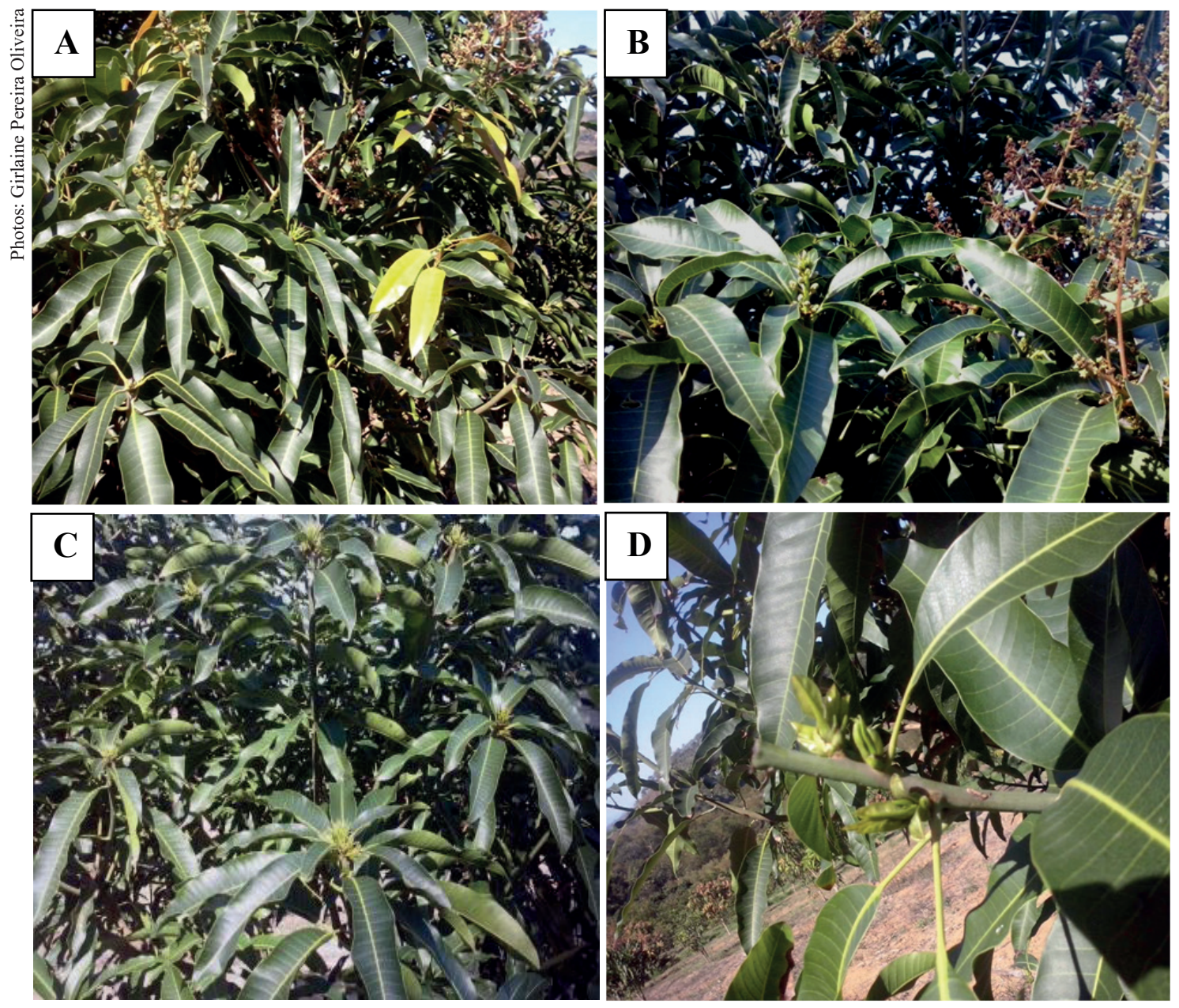

Figure 2. Flowering of 'Ubá' mango trees: flowering uneven uniformity in plants that were not pruned (A and B) and uniformity in the emission of floral buds on pruned plants without (C) and with branch tip pruning (D). 
for the 'Rosa', 'Bourbon' and 'Tommy Atkins' cultivars. For the 'Rosa' and 'Bourbon' cultivars, a high flowering percentage was observed with the paclobutrazol dose of $0.8 \mathrm{~g}$ per linear meter of canopy, as well as $1.5 \mathrm{~g} \mathrm{~m}^{-1}$ for the 'Tommy Atkins' cultivar.

The response of mango trees to the paclobutrazol application is different for each cultivar, and cultivars that have an intense vegetative capacity require higher paclobutrazol doses to control sprouting (Albuquerque et al. 2002). The 'Ubá' mango cultivar is in the group with intense vegetation capacity (Faraoni et al. 2009).

For 'Ubá' mango trees, the highest number of panicles per branch was obtained at the dose of
$0.5 \mathrm{~g} \mathrm{~m}^{-1}$, in plants submitted to branch tip pruning (Table 2). This result was also observed by Oliveira et al. (2015), with 'Palmer' mango, in northern Minas Gerais State.

Branch tip pruning reduces the auxin synthesis at the apex of branches (Taiz \& Zeiger 2012), directing the transport of assimilates and cytokinins to the axillary buds of branches under flowering conditions, inducing the formation of axillary inflorescences (Srivastava 2002).

The total number of flowers per panicle was lower in plants submitted to tip pruning (Figure 4A), but no significant differences were observed in response to paclobutrazol doses (Table 1). The relationship between male and hermaphrodite flowers

Table 1. Mean flowering percentage (FP), number of panicles per branch (NPB), number of male flowers per panicle (MF), number of hermaphrodite flowers per panicle (HF), male/hermaphrodite flowers ratio (MHR), total number of flowers per panicle (TFP) and number of fruits per branch (NFB) in 'Ubá' mango trees submitted to paclobutrazol doses, with and without branch tip pruning.

\begin{tabular}{|c|c|c|c|c|c|c|c|c|c|}
\hline \multicolumn{3}{|c|}{ Treatment } & \multirow[b]{2}{*}{ FP } & \multirow[b]{2}{*}{ NPB } & \multirow[b]{2}{*}{$\mathrm{MF}$} & \multirow[b]{2}{*}{$\mathrm{HF}$} & \multirow[b]{2}{*}{ MHR } & \multirow[b]{2}{*}{ TFP } & \multirow[b]{2}{*}{ NFB } \\
\hline & Dose $\left(\mathrm{g} \mathrm{m}^{-1}\right)$ & Tip pruning & & & & & & & \\
\hline $\mathrm{T} 1$ & 0.0 & With & $83.55^{*}$ & $2.62 *$ & 795.25 & $87.25^{*}$ & 9.81 & 882.50 & $4.18^{*}$ \\
\hline $\mathrm{T} 2$ & 0.0 & Without & 41.00 & 1.23 & $1,370.00$ & 161.00 & 9.46 & $1,530.50$ & 2.56 \\
\hline $\mathrm{T} 3$ & 0.5 & With & $91.62 *$ & $4.04 *$ & $1,266.25$ & 128.75 & 10.82 & $1,395.00$ & 3.75 \\
\hline $\mathrm{T} 4$ & 0.5 & Without & $61.31 *$ & 1.18 & $1,225.50$ & $67.00 *$ & 20.11 & $1,318.75$ & 1.87 \\
\hline $\mathrm{T} 5$ & 1.0 & With & $83.31 *$ & $2.71 *$ & $1,040.50$ & $89.75^{*}$ & 17.44 & $1,130.25$ & 3.37 \\
\hline T6 & 1.0 & Without & $58.67^{*}$ & 1.40 & $1,580.25$ & $75.75^{*}$ & 41.60 & $1,656.00$ & 2.00 \\
\hline $\mathrm{T} 7$ & 1.5 & With & $84.22 *$ & $3.21 *$ & $1,424.00$ & $43.25^{*}$ & 34.64 & $1,467.25$ & 3.25 \\
\hline $\mathrm{T} 8$ & 1.5 & Without & $61.96^{*}$ & 1.28 & $1,881.25$ & $83.75^{*}$ & 33.29 & $1,965.00$ & 1.81 \\
\hline T9 & 2.0 & With & $92.70 *$ & $3.25 *$ & $1,046.25$ & $97.25^{*}$ & 19.67 & $1,143.50$ & 2.75 \\
\hline $\mathrm{T} 10$ & 2.0 & Without & $61.70^{*}$ & 1.25 & $1,466.25$ & $39.00 *$ & 46.66 & $1,505.25$ & 1.56 \\
\hline $\mathrm{T} 11$ & Control & & 44.89 & 1.19 & $1,515.25$ & 168.75 & 12.14 & $1,661.50$ & 2.68 \\
\hline Overa & & & 69.53 & 2.12 & $1,328.25$ & 94.68 & 23.24 & $1,423.22$ & 2.56 \\
\hline
\end{tabular}

Means with $*$ in the column differ from the control at $5 \%$ by the Dunnett test.
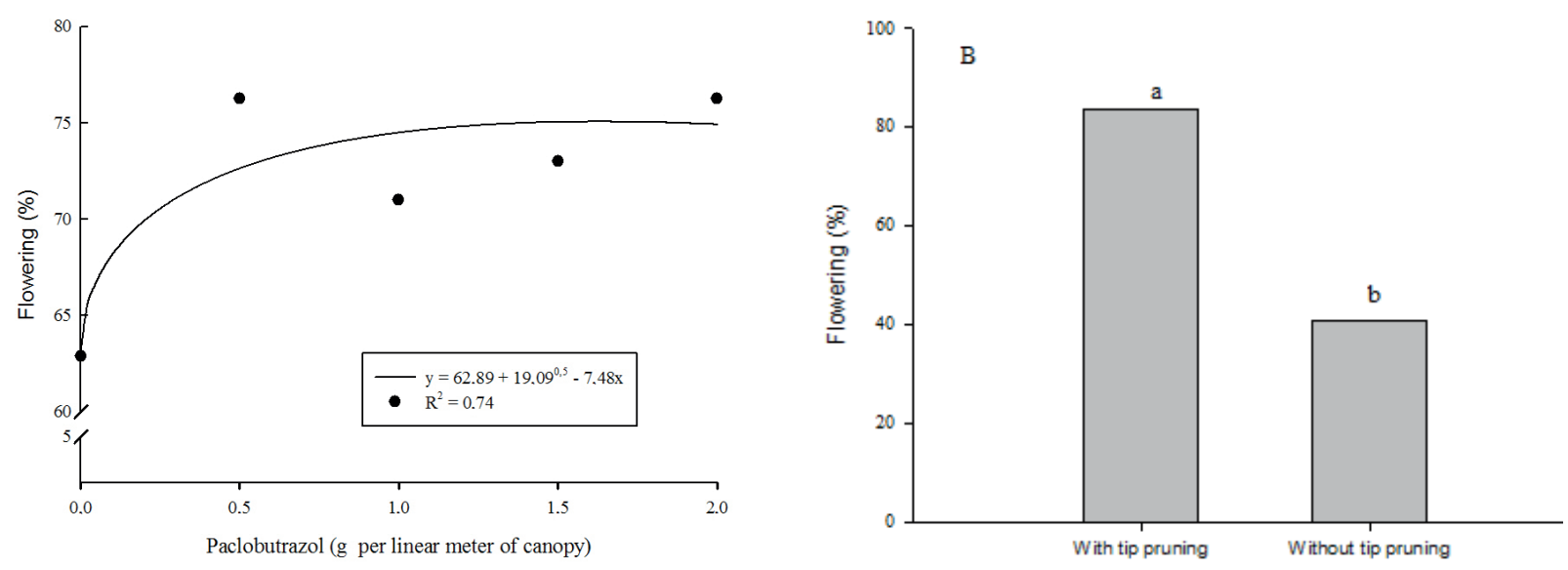

Figure 3. Flowering percentage of 'Ubá' mango trees at different paclobutrazol doses (A) and with and without branch tip pruning (B). 
in the panicle increased with the increase in paclobutrazol doses, with a mean maximum value of 32 at the dose of $2 \mathrm{~g}$ per linear meter of canopy (Figure 4B).

The higher number of panicles per branch caused by tip pruning probably reduced the panicle size and, consequently, the number of flowers in the panicle. Due to the greater number of panicles in the branch, there is a greater competition for photoassimilates (García de Niz et al. 2014) and, consequently, inflorescences become smaller and with fewer flowers. Despite the reduction in the number of flowers in the inflorescence, the mean number of flowers in the present study $(1,423)$ was higher than that found by Lemos (2014), who observed a mean of 1,300 flowers in the panicle of 'Ubá' mango trees, in 2012.

The higher male/hermaphrodite flowers ratio is not in agreement with the results obtained by Singh (2001), who reported that the paclobutrazol application increases the relation of hermaphrodite flowers in the mango tree panicles. Luminosity and temperature are environmental factors of great influence on the sexual expression of mango trees (Lima-Filho et al. 2002, Lemos 2014). LimaFilho et al. (2002) suggests that the proportion of hermaphrodite flowers in the panicle may vary $2-75 \%$, depending on the climate and location of the panicle in the plant.

Branch tip pruning increased the number of fruits per branch (average of 3.46 fruits in the branch), while plants not submitted to tip pruning showed an average of 1.96 fruits per branch. The high number of panicles per branch (Table 2) observed in plants submitted to tip pruning contributed to increase the number of fruits per branch.

There were no significant differences among treatments for the following fruit characteristics: fruit length and diameter, pulp yield, peel hue angle, pulp hue angle, total soluble solids, pulp acidity and total soluble solids/pulp acidity ratio, in 'Ubá' mango fruits treated with different paclobutrazol doses and tip pruning.

The mean fruit length and diameter were $7.34 \mathrm{~cm}$ and $5.37 \mathrm{~cm}$, respectively. According to García de Niz et al. (2014), fruit size is inversely

Table 2. Mean number of panicles per branch of 'Ubá' mango tress submitted to paclobutrazol doses and with and without branch tip pruning.

\begin{tabular}{lcccccc}
\hline \multirow{2}{*}{\multicolumn{1}{c}{ Treatment }} & \multicolumn{5}{c}{ Panicles per branch } & \multirow{2}{*}{ Regression } \\
\cline { 2 - 5 } & \multicolumn{4}{c}{ Paclobutrazol dose (g per linear meter of canopy) } & \\
\cline { 2 - 5 } & 2.0 & 0.5 & 1.0 & 1.5 & 2.0 & \\
\hline With branch tip pruning & $2.62 \mathrm{a}$ & $4.04 \mathrm{a}$ & $2.70 \mathrm{a}$ & $3.21 \mathrm{a}$ & $3.25 \mathrm{a}$ & $\hat{\mathrm{y}}=3.09 \mathrm{a}$ \\
Without branch tip pruning & $1.23 \mathrm{~b}$ & $1.18 \mathrm{~b}$ & $1.40 \mathrm{~b}$ & $1.28 \mathrm{~b}$ & $1.25 \mathrm{~b}$ & $\hat{\mathrm{y}}=1.27 \mathrm{~b}$ \\
\hline
\end{tabular}

Means followed by different letters in the columns differ by the tukey test at $5 \%(\mathrm{p}<0.05)$.
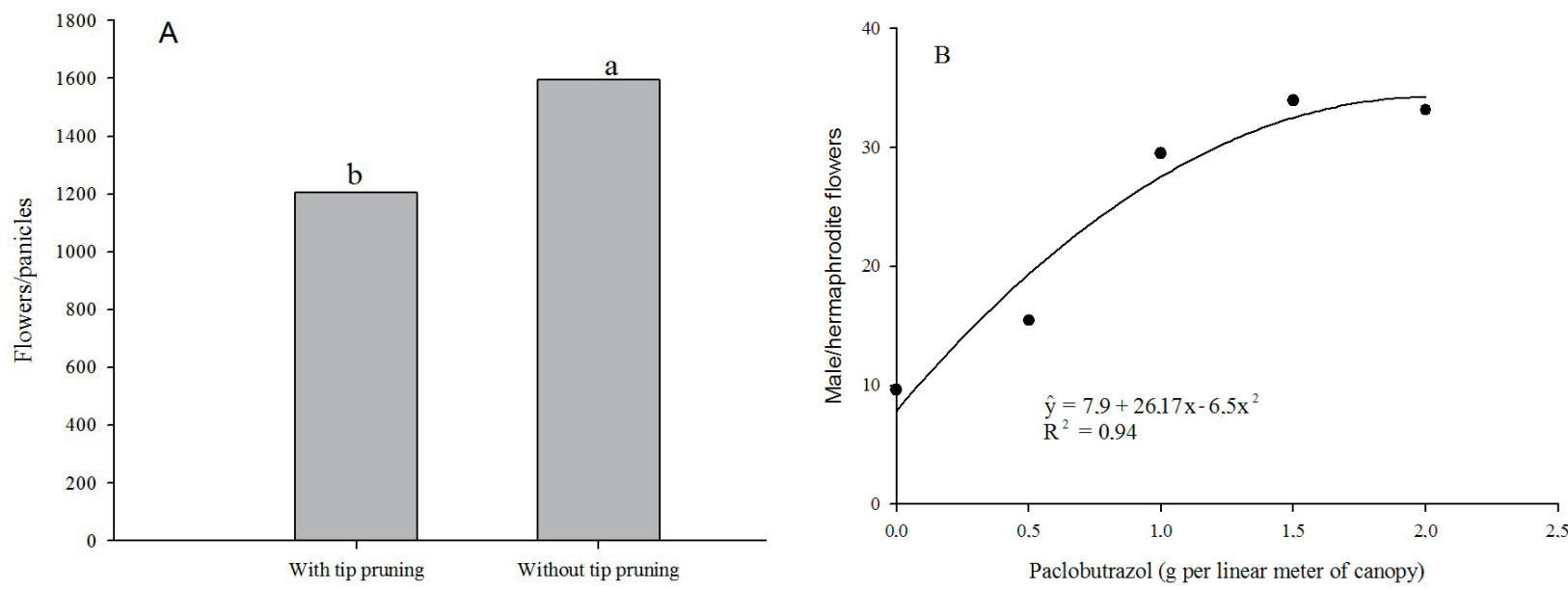

Figure 4. Mean number of flowers in the panicle of 'Ubá' mango trees with and without branch tip pruning. (A) Mean number of male/hermaphrodite flowers in the panicle at different paclobutrazol doses (B). 
related to fruit production per plant, due to the competition between drains. The high number of fruits per branch, due to tip pruning, was not sufficient to change the source/drain relation in 'Ubá' mango trees, due to the fact that this cultivar is vigorous and has received adequate nutritional management.

The mean fruit mass was $123.10 \mathrm{~g}$. For the agro-industries of the "Zona da Mata", the fruit mass and size are not very important, since the fruit is destined to the production of juice (Silva et al. 2009). The mean pulp yield of fruits was $65 \%$, being close to values found by Silva et al. (2009) and Oliveira et al. (2013), from $61 \%$ and $69 \%$, respectively, for the 'Ubá' cultivar. The use of fruits with high pulp yields is important for industrial processing. Even not presenting high pulp yields, if compared to the 'Palmer' (80.6\%) and 'Tommy Atkins' cultivars (75\%) (Silva et al. 2009), the 'Ubá' cultivar has other favorable characteristics, such as flavor, high sugar content and pulp color, which make them more attractive to industries.

The mean content of total soluble solids was $19.6^{\circ}$ Brix and the mean titratable acidity was $0.48 \%$ of citric acid. Reis et al. (2011) did not find significant differences in the evaluation of total soluble solids and titratable acidity in 'Haden' mangoes submitted to different paclobutrazol doses produced in Jaíba, Minas Gerais State. However, in the 'Palmer' mango cultivar, the increase in the paclobutrazol dose reduced the content of soluble solids from $16{ }^{\circ} \mathrm{Brix}$ to $13{ }^{\circ}$ Brix (Oliveira et al. 2015), with the lowest values being found in fruits whose plants received the paclobutrazol dose of $0.9 \mathrm{~g}$ per linear meter of canopy. These different responses may be related to genotype, since, in some cultivars, the soluble solids contents decrease with the application of paclobutrazol.

The TSS/TA ratio presented general average of 41.79. Similar values were observed by some authors for 'Ubá' mango trees in the "Zona da Mata" region (Oliveira et al. 2013, Rufini et al. 2010), who found mean values between 18.8 and 65 . The ratio has been used to evaluate the fruit flavor, as it increases with maturation (Chitarra \& Chitarra 2005).

This study shows promising results on flowering induction, however, further studies with paclobutrazol should be carried out, in order to evaluate the continuous effect of this growth regulator on 'Ubá' mango tree cultivation.

\section{CONCLUSION}

Branch tip pruning and paclobutrazol application are efficient in inducing the flowering of 'Ubá' mango trees, without changing fruit quality.

\section{REFERENCES}

ALBURQUEQUE, J. A. S.; MEDINA, V. D.; MOUCO, M. A. D. Indução floral. In: GENU, P. J. C.; PINTO, A. C. Q. A cultura da mangueira. Brasília, DF: Embrapa Informação Tecnológica, 2002. p. 259-276.

ASSOCIATION OF OFFICIAL AGRICULTURAL CHEMISTS (AOAC). Official methods of analysis of the Association of Official Analytical Chemists International. Washington, DC: AOAC, 1997.

CARDOSO, M. G. S. et al. Florescimento e frutificação de mangueira (Mangifera indica L.) cv. Rosa promovidos por diferentes doses de paclobutrazol. Revista Brasileira de Fruticultura, v. 29, n. 2, p. 209-212, 2007.

CHATZIVAGIANNIS, M. A. et al. Florescimento e produtividade de mangueira 'Boubon', 'Palmer' e 'Rosa' com uso de paclobutrazol. Revista Iberoamericana de Tecnología Postcosecha, v. 15, n. 1, p. 41-47, 2014.

CHITARRA, M. I. F.; CHITARRA, A. B. Pós-colheita de frutas e hortaliças: fisiologia e manuseio. Lavras: UFLa, 2005.

COELHO, E. F. et al. Flowering and fruit set of mango in different doses of paclobutrazol (PBZ). Enciclopédia Biosfera, v. 10, n. 19, p. 1117, 2014.

DAVENPORT, T. L. Pruning strategies to maximize tropical mango production from the time of planting to restoration of old orchards. Hortscience, v. 41, n. 3, p. 544-548, 2006.

DAVENPORT, T. L. Reproductive physiology of mango. Brazilian Journal of Plant Physiology, v. 19, n. 4, p. 363376, 2007.

DAVENPORT, T. L.; NÚÑEZ-ELISÉA, R. Reproductive physiology. In: LITZ, R. E. (Ed.). The mango: botany, production and uses.Wallingford: CAB International, 1997. p. 69-146.

GARCÍA DE NIZ, D. A. et al. Vegetative and reproductive development of 'Ataulfo' mango under pruning and paclobutrazol management. Journal of Agricultural Science and Tecnology, v. 16, n. 2, p. 385-393, 2014.

LEMOS L. M. C. Controle do amadurecimento e da antracnose na pós-colheita da manga 'Ubá'. 2014. 133 f. Tese (Doutorado em Fitotecnia) - Universidade Federal de Viçosa, Viçosa, 2014. 
LIMA-FILHO, J. M. P. et al. Ecofisiologia. In: GENÚ, P. J. C.; PINTO, A. C. Q. A cultura da mangueira. Brasília, DF: Embrapa Informação Tecnológica, 2002. p. 37-50.

MOUCO, M. A. C. et al. Controle do crescimento vegetativo e floração de mangueiras cv. Kent com reguladores de crescimento vegetal. Revista Brasileira de Fruticultura, v. 33, n. 4, p. 1043-1047, 2011.

MOUCO, M. A. C. et al. Mango flower induction in the Brazilian northeast semi-arid with gibberellin synthesis inhibitors. Acta Horticulture, n. 884, p. 591-596, 2010.

MOUCO, M. A. C.; ALBURQUEQUE, J. A. S. Efeito do paclobutrazol em duas épocas de produção da mangueira. Bragantia, v. 64, n. 2, p. 219-225, 2005.

OLIVEIRA, G. P. et al. Caracterização de acessos de mangueira 'Ubá' na Zona da Mata Mineira. Ciência Rural, v. 43, n. 6, p. 962-969, 2013.

OLIVEIRA, M. B. et al. Paclobutrazol and tip pruning in the management of 'Palmer' mango trees in the semiarid region of Brazil. Acta Horticulture, v. 1075, n. 16, p. 149-156, 2015.

PINTO, C. A. Q. et al. Mangueira. In. CRISOSTOMO, L. A.; NAUMOV,A. (Orgs.). Adubando para alta produtividade e qualidade: fruteiras tropicais do Brasil. Fortaleza: Embrapa Agroindústria Tropical, 2009. p. 125-145.
REIS, J. B. R. S. et al. Efeito da lâmina de irrigação e doses de PBZ na pós-colheita da mangueira cv. Haden no norte de Minas Gerais. Revista Brasileira de Agricultura Irrigada, v. 5, n. 3, p. 214-224, 2011.

RUFINI, J. C. M. et al. Caracterização biométrica e físicoquímica dos frutos de acessos de manga Ubá. Revista Brasileira de Fruticultura, v. 33, n. 2, p. 456-464, 2010.

SILVA, D. F. P. et al. Amadurecimento de manga 'Ubá' com etileno e carbureto de cálcio na pós-colheita. Ciência Rural, v. 42, n. 2, p. 213-220, 2012.

SILVA, D. F. P. et al. Caracterização de frutos de 15 cultivares de mangueira. Revista Ceres, v. 56, n. 6, p. 783789, 2009.

SINGH, D. K. Triazole compounds in horticulture. New Delhi: Agrotech Publishing Academy, 2001.

SISTEMA PARA ANÁLISE ESTATÍSTICA (Saeg). Versão 9.1. Viçosa, MG: Fundação Arthur Bernardes, 2007.

SRIVASTAVA, L. M. Plant growth and development: hormones and the environment. New York: Academic Press, 2002.

TAIZ, L.; ZEIGER, E. Fisiologia vegetal. 5. ed. Porto Alegre: Artmed, 2012. 